\title{
Guidelines for phytosociological classifications and descriptions of vegetation in southern Africa
}

\begin{tabular}{|c|c|}
\hline \multicolumn{2}{|c|}{$\begin{array}{l}\text { Authors: } \\
\text { Leslie R. Brown }{ }^{1} \\
\text { Pieter J. du Preez } \\
\text { Hugo Bezuidenhout }^{1,3} \\
\text { George J. Bredenkamp } \\
\text { Theo H.C. Mostert }{ }^{5} \\
\text { Nacelle B. Collins }\end{array}$} \\
\hline \multicolumn{2}{|c|}{$\begin{array}{l}\text { Affiliations: } \\
{ }^{1} \text { Applied Behavioural Ecology } \\
\text { and Ecosystem Research } \\
\text { Unit, University of South } \\
\text { Africa, South Africa }\end{array}$} \\
\hline \multicolumn{2}{|c|}{$\begin{array}{l}{ }^{2} \text { Department of Plant } \\
\text { Sciences, University of the } \\
\text { Free State, South Africa }\end{array}$} \\
\hline \multicolumn{2}{|c|}{$\begin{array}{l}{ }^{3} \text { South African National Parks } \\
\text { Scientific Services, Hadison } \\
\text { Park, Kimberley, South Africa }\end{array}$} \\
\hline \multicolumn{2}{|c|}{$\begin{array}{l}{ }^{4} \text { Department of Plant } \\
\text { Science, University of } \\
\text { Pretoria, South Africa }\end{array}$} \\
\hline \multicolumn{2}{|c|}{$\begin{array}{l}{ }^{5} \text { Department of Botany, } \\
\text { University of Zululand, } \\
\text { South Africa }\end{array}$} \\
\hline \multicolumn{2}{|c|}{$\begin{array}{l}{ }^{6} \text { Free State Department of } \\
\text { Economic Development, } \\
\text { Tourism \& Environmental } \\
\text { Affairs, Bloemfontein, } \\
\text { South Africa }\end{array}$} \\
\hline \multicolumn{2}{|c|}{$\begin{array}{l}\text { Correspondence to: } \\
\text { Leslie Brown }\end{array}$} \\
\hline \multicolumn{2}{|c|}{$\begin{array}{l}\text { Email: } \\
\text { Irbrown@unisa.ac.za }\end{array}$} \\
\hline \multicolumn{2}{|c|}{$\begin{array}{l}\text { Postal address: } \\
\text { Private Bag X6, Florida 1710, } \\
\text { South Africa }\end{array}$} \\
\hline \multicolumn{2}{|c|}{$\begin{array}{l}\text { Received: } 25 \text { July } 2012 \\
\text { Accepted: } 29 \text { Apr. } 2013 \\
\text { Published: } 23 \text { July } 2013\end{array}$} \\
\hline \multicolumn{2}{|c|}{$\begin{array}{l}\text { How to cite this article: } \\
\text { Brown, L.R., Du Preez, } \\
\text { P.J., Bezuidenhout, } \\
\text { H., Bredenkamp, G.J., } \\
\text { Mostert, T.H.C. \& Collins, } \\
\text { N.B., 2013, 'Guidelines } \\
\text { for phytosociological } \\
\text { classifications and } \\
\text { descriptions of vegetation } \\
\text { in southern Africa', Koedoe } \\
\text { 55(1), Art. \#1103, } 10 \text { pages. } \\
\text { http://dx.doi.org/10.4102/ } \\
\text { koedoe.v55i1.1103 }\end{array}$} \\
\hline Read online: & \\
\hline 口仿回 & $\begin{array}{l}\text { Scan this } Q R \\
\text { code with your } \\
\text { smart phone or } \\
\text { mobile device } \\
\text { to read online. }\end{array}$ \\
\hline
\end{tabular}

Changes in the environment are first observed in changes in the vegetation. Vegetation survey, classification and mapping form the basis on which informed and scientifically defendable decisions on the environment can be taken. The classification and mapping of vegetation is one of the most widely used tools for interpreting complex ecosystems. By identifying different plant communities we are essentially identifying different ecosystems at a particular hierarchical level. Phytosociologists in Europe have been involved in such studies following, in particular, the Braun-Blanquet approach since the early 1900s. In South Africa, such studies were undertaken on a limited basis from the early 1970s and have since then steadily increased. The surveying of the enormous diversity of South African vegetation is one of the objectives of phytosociological studies. The demand for such data has steadily increased over the past few years to guide conservation policies, biodiversity studies and ecosystem management. In South Africa, numerous publications on the vegetation of conservation and other areas in the different biomes have been produced over the last few decades. However, vegetation scientists in South Africa experience unique problems. The purpose of this article is therefore to provide an overview of the history and the specific focus of phytosociological studies in South Africa and to recommend minimum requirements and methods to be followed when conducting such studies. It is believed that the incorporation of these requirements will result in scientifically justifiable research of high quality by phytosociologists in South Africa.

Conservation implications: Effective conservation cannot be obtained without a thorough knowledge of the ecosystems present in an area. Consistent vegetation classifications and descriptions form the basis of conservation and monitoring exercises to maintain biodiversity. The incorporation of these guidelines and requirements will facilitate quality phytosociological research in South Africa.

\section{Introduction}

One of the earliest examples of an informal description of southern African vegetation dates back to the late 1400s. In December 1497, Vasco da Gama sailed from Mossel Bay in an easterly direction, ensuring that he always had sight of the terrestrial land. Interestingly he made no mention of the different wild animals, but instead he continually referred to the vegetation they observed on the land (Skead 2011). Since then people have used vegetation to assist with finding their way in and around the African continent. Vegetation is the most physical representation of the environment (Kent 2012). Any spatial and temporal changes in habitats are first observed in the vegetation. As a result, the mapping and description of vegetation has either informally or formally played an important role as a tool to classify and interpret different ecosystems.

These assessments led to the development of the discipline of vegetation science (plant ecology), and its various fields of specialisation, of which synecology (the classification, description and mapping of vegetation, succession and dynamics) (Barbour, Burk \& Pitts 1987) is an important field. Synecology stems from observations of the great variety of form and structure of plants that repeat themselves in similar environmental conditions. Vegetation scientists started to explore the world to describe and map the diverse plant life of the planet. In the early 20th century most vegetation scientists in Europe were occupied with the phytosociological (phyto = plant; sociology = groupings of species) classification, description and mapping of the continents' vegetation.

Professor V. Westhoff once commented that phytosociology is the science of recognising and identifying the stepping stones in vegetation within the overwhelming swamp of variation (Bredenkamp 1982; Mostert 2006). Currently, vegetation classification and mapping is one of the most widely used tools to assist in the interpretation of complex ecosystems and to simplify the spatial and temporal complexity of these ecosystems (Doing 1970; Mucina \& Rutherford

Note: Additional supporting information may be found in the online version of this article as an Online Appendix $1 \mathrm{http}: / / \mathrm{dx}$.doi. org/10.4102/koedoe.v55i1.1103-1 and Online Appendix 2 http://dx.doi.org/10.4102/koedoe.v55i1.1103-2.

Copyright: ๑ 2013. The Authors. Licensee: AOSIS OpenJournals. This work is licensed under the Creative Commons Attribution License. 
2006). Vegetation also fulfils an important function in that it provides food and shelter for wildlife (Mucina \& Rutherford 2006; Skead 2011).

Modern scientific society uses phytosociology either to form the background of scientific studies on animals (e.g. Henzi et al. 2011; Hirst 1975; Pasternak et al. 2013) or to define different plant communities, which could be unique in the sense of rare or endangered plant species (e.g. Du Preez \& Brown 2011; Edge, Cilliers \& Terblanche 2008; Gotze et al. 2008; Janecke, Du Preez \& Venter 2003). Results of phytosociological studies should be the foundation for informed decisions on wildlife management and nature conservation. Phytosociology not only serves as the backbone of ecosystem studies but also forms part of the planning for monitoring plant species or communities and rare or endangered ecosystems. Vegetation is a collective term for all the plant communities in the same way that flora is a collective term for all the plant species. We describe plant communities, not 'vegetation communities'.

With climate change, phytosociological studies will become more important because, in most cases, only vegetation data are available to use for comparisons. Data collected according to accepted quantitative methods, can be used to give detailed information about plant species abundance and also a description of the structure of the vegetation. Such data can also be used for gradient analyses, measuring plant species diversity, the study of successional changes and measuring plant production of different ecosystems. Vegetation classification is also useful to assist in making informed decisions on the habitat that is available for wildlife, as well as making informed decisions on fire policy and programmes aimed at clearing alien plant species.

Detailed vegetation classification, mapping and description also form the basis from which informed and scientifically defendable decisions can be taken for infrastructure and other development in an area. It also assists with impact assessment for development purposes. When the expansion of conservation areas is considered, the results of phytosociological studies should be used to assist with planning of these expansions to guide conservation decisions about important, scarce or rare plant communities.

At an appropriate scale (association level), plant communities can thus be used as surrogates for ecosystem delineations with very high accuracy. This ability of vegetation to act as a surrogate for ecosystem descriptions or delineations is seated in the fact that vegetation is a highly visible and measurable biological manifestation of all the other environmental factors shaping and driving a specific ecosystem (Barbour et al. 1987; Kent 2012).

Phytosociology is used in many different research fields in nature conservation, (e.g. mammalogy, ornithology, herpetology, entomology, geology, soil science, landscape ecology, limnology, etc.) to describe the habitat and give the reader an idea of the (expected) species composition and vegetation structure. It is therefore important that vegetation description studies should be as comprehensive as possible.
With the current pressure on the environment, and especially natural vegetation, as a result of mining and agricultural activities. as well as urban and rural development, the need for proper planning cannot be underestimated. Although the need for mining or agricultural development sometimes supersedes conservation importance, vegetation classification and description is important to identify ecologically sensitive areas. These studies are currently compulsory in South Africa in terms of the National Environmental Management: Biodiversity Act (Act No. 10 of 2004) (South African Government 2004).

By identifying different plant communities, we are essentially identifying different ecosystems at a particular hierarchical level. Plant communities and their associated vegetation maps are therefore regarded as reliable surrogates for the demarcation of macro-ecosystems. Describing, monitoring and managing the surrogate (plant community) are the first steps in effectively monitoring and managing the entire ecosystem, without trying to understand and manage the bewildering detail of all the different components and interactions of the ecosystem. Vegetation surveys, classification and mapping provide a framework for understanding the differences between ecosystems (Chytrý, Schaminee \& Schwabe 2011). Although this approach to ecosystem management is not fail safe or without its shortcomings, it provides ecologists with a sensible, tangible tool and first approximation for the management of ecosystem patterns and processes.

\section{Purpose of this article}

Phytosociological research has a long history. However, vegetation scientists in South Africa are experiencing various problems that do not occur elsewhere in the world (see later). The purpose of this article is to provide an overview of the history of phytosociological studies in South Africa and to recommend broad guidelines on the minimum requirements and methods to be followed when conducting vegetation classification, description, habitat interpretation studies and mapping following the Braun-Blanquet approach.

\section{History of phytosociology in South Africa}

We attempt to present a brief history of the development of phytosociology in South Africa using a few examples for explanation, rather than giving a complete review of all the phytosociological research conducted or publications that have appeared on South African vegetation during the last century.

Most of the earlier national and regional studies were mainly of a non-formal descriptive nature (e.g. Bayer 1955; Bews 1918; Dyer 1937; Edwards 1967; Killick 1963; Louw 1951; Muir 1929; Pole Evans 1922), often providing only species lists of a particular area. Acocks (1953) classified the South African vegetation into 70 veld types and 75 variations based on comparison of floristics from stand data. He recorded the abundances of all species. 
Consequently, many South African vegetation scientists used a more flexible approach. Statistical numerical classification methods were applied as a first approximation of the plant communities in a particular area, but with the option to 'refine' the classification by applying ZurichMontpellier methods. Relevés could be moved to other clusters (if deemed necessary) by considering more factors (especially total floristic composition, diagnostic species and habitat interpretation) than only those used by the particular numerical algorithm (Bredenkamp 1982). Application of the TWINSPAN classification algorithm (Hill 1979) made a major contribution to obtain more objectivity and repeatability in the classification whilst simultaneously retaining the advantages of a phytosociological table. This provided not only the hierarchical classification and total floristic composition of each plant community at different levels, but also a valuable overview of species cover and abundance, constancy, fidelity and the habitat. The phytosociological table thus became a necessity in every phytosociological study. As computer software became more readily available, the TURBOVEG programme was developed to serve as a standardised format for the storage and management of vegetation data (Hennekens 1996; Hennekens \& Schaminee 2001).

Apart from the pioneering studies of Werger (1973) and Van der Meulen (1979), which were considered to be regional studies, the majority of the earlier studies by South African researchers were more local in extent. The goals of sustainable utilisation linked with effective conservation cannot be achieved without a thorough knowledge of the ecology of a particular area (Edwards 1972; Werger 1974). It was therefore recommended that conservation policies and environmental management plans should be based on this knowledge (Edwards 1972). This resulted in many phytosociological projects initiated in nature conservation areas (e.g. national parks, provincial nature reserves or privately owned and managed game reserves), which resulted in numerous publications on the vegetation of conservation areas in the different biomes of South Africa.

Selected examples include:

- Grassland: Bloem (1988), Bredenkamp (1975), Coetzee (1972), Kay, Bredenkamp and Theron (1993) and Swanepoel (2006).

- Savanna: Bezuidenhout (1994), Brown (1997), Gertenbach (1978), Mostert (2006), Stalmans and Peel (2010), Van Rooyen (1983) and Van Staden (2002).

- Nama-Karoo: Brown and Bezuidenhout (2000), Cleaver, Brown and Bredenkamp (2005), Rubin and Palmer (1996), Van der Walt (1980) and Werger and Coetzee (1977).

- Succulent Karoo: Jurgens (2004) and Le Roux (1984).

- Fynbos: Boucher (1997), McDonald (1988), Zietsman (2003) and Zietsman and Bredenkamp (2006).

- Forest: Geldenhuys and Murray (1993), Grobler (2009) and Matthews et al. (2001).

- Thicket: Palmer (1981).

- Azonal units: Collins (2011), Du Preez and Brown (2011) and Pretorius (2012).
- Additional regional studies: Bezuidenhout (1993), Du Preez (1991), Eckhardt (1993), Fuls (1993), Hoare (1997) and Kooij (1990).

\section{Recommended minimum requirements for phytosociological studies in South Africa}

To achieve the goal of syntaxonomic synthesis of southern African vegetation and to attain internationally acceptable standards for local studies in, for example, national parks, nature reserves, private game farms and other conservation areas, we strongly recommend the following minimum requirements for phytosociological studies in southern Africa.

\section{Approach}

We recommend that the Zurich-Montpellier (BraunBlanquet) school of total floristic compositions (BraunBlanquet 1932; Kent 2012; Mueller-Dombois \& Ellenberg 1974; Werger 1973; Westhoff \& Van der Maarel 1978) should be followed. The main benefit of this approach is that much of the world's vegetation has been and is continued to be surveyed and classified according to a relatively uniform protocol (Chytrý et al. 2011).

\section{Principles}

- Sample plot placement is not subjective as originally proposed by Braun-Blanquet (1932), but placed in a stratified random manner within floristically uniform units because it is accepted that each of these units represents a single plant community.

- The vegetation in a sample plot must be representative of a single plant community. Therefore, a minimum plot size for the particular plant community is used.

- The sample plot must be uniform with regard to its biophysical make-up. Independent of the scale of the study, floristically homogeneous units that can physically be identified and managed in the field must be used to define plant communities. Large scale-related heterogeneous sample plots are avoided as they will result in mixed relevés containing species from different plant communities and a range of biophysical features. These mixed relevés are not according to the basic ZurichMontpellier principle of sampling within homogeneous units. Mixed relevés are difficult to interpret ecologically and to assign to a specific recognisable plant community. The classification of mixed relevés groups unrelated communities together and may ignore smaller and sometimes threatened or endangered ecosystems.

- Ideally, all species present in the sample plot should be identified and recorded during the time of survey. Owing to seasonality and natural impacts (e.g. grazing, fire, irregular rainfall, erosion, flooding, droughts, etc.), especially in arid and semi-arid areas, some plant species are not easily identifiable (Werger 1973). In addition, the rich floristic diversity of South Africa and the many 
cryptic species result in taxonomical problems owing to several undescribed and often unidentifiable species (e.g. some mesembs, orchids, geophytes and annuals).

\section{Field survey methods}

The following field survey methods are recommended:

- Stratified random placement should be determined during the desktop phase whilst preparing for fieldwork. Stratification of the vegetation can be performed by means of a geographic information system (GIS) using a number of environmental data overlays in combination with satellite and aerial imagery. Applicable spatial environmental data overlays include landscapes, land types, terrain units, topography, altitude, climate, geology, soil characteristics, surface rock cover, land use, land cover, or any other relevant spatial data set. Overlaying these data sets onto available aerial and satellite imagery will aid in the accurate delineation of relatively homogeneous vegetation units. Placement of sample plots within each homogeneous vegetation-cumhabitat unit should be random. In the field, however, the randomly determined location of each sampling plot should be critically evaluated according to the first rule of the Zurich-Montpellier sampling method (placement of the sampling plot should be within a homogeneous vegetation patch representative of the perceived plant community). If the sampling plot does not fall within a homogeneous representative vegetation stand, it should be moved to the nearest locality that does fulfil this criterion.

- A minimum plot size should be determined based on species-area curves produced for each physiognomicphysiographic unit sampled (Kent 2012). It is important to note that when gathering data to determine such speciesarea curves, the first rule of the Braun-Blanquet method (placement of the nested set of progressively larger plots within a homogeneous vegetation stand, representative of the perceived plant community) should be observed very strictly. Alternatively, the researcher may use plot sizes similar to those used in other successful BraunBlanquet surveys in similar physiognomic-physiographic units. The researcher should refer to available literature and clearly state the aspects of similarity between the vegetation described with the various plant communities occurring in the study area. The plot sizes given in Table 1 may be used as a guideline for the relevant vegetation to be sampled.

- For formal syntaxonomic classification, Weber, Moravec and Theurillat (2000) states that only one relevé is required for a formal description of a syntaxon (plant community) although a minimum of ten plots are recommended. To comply with statistical requirements in local phytosociological studies, a minimum of three sampling plots for each of the stratified physiognomicphysiographic units is recommended. Exceptions to this suggestion may be in the case of azonal vegetation covering so little of the study area that the placement of more than two plots may lead to pseudo-replication. The required minimum number of plots will depend largely on the size of the plant community in question, being less in smaller plant communities. The description of plant communities based on one or two relevés should be strongly discouraged and such communities should be regarded as doubtful units (Weber et al. 2000).

- Apart from compiling all existing environmental data during the preparation for fieldwork (desktop GIS), as many as possible of the following environmental parameters should be measured and determined in the field at each sampling plot during the actual fieldwork phase (recommended but not limited to): geology, surface rock cover, land type, terrain form, soil depth, soil form, soil texture, soil structure, altitude, coordinates, aspect and slope.

- Soil samples should preferably be collected at the average rooting depth utilised by the vegetation that is being studied. Where the soil is classified, the diagnostic horizon from which the sample was taken should be noted.

- South Africa's vegetation is highly dependent on rainfall, which is, in most cases, seasonal and erratic. It is recommended that a survey be conducted during the optimal growth period. The period of field survey should be stated clearly.

- Cover-abundance values for each species recorded within a sample plot should be estimated using one of the many compatible cover-abundance scales used in current phytosociological studies (e.g. modified Braun-Blanquet cover scale, Domin cover scale, Plant-number scale) (Kent 2012; Westfall et al. 1996). In current southern African surveys, the modified Braun-Blanquet cover-abundance scale is preferred for vegetation classification studies.

\section{Data analysis}

\section{Vegetation classification}

- It is recommended that phytosociological data are captured in a format that can be imported into programs such as JUICE (Tichý \& Holt 2006).

- Algorithms assume that the data have a normal distribution. Data should be tested for normality (e.g. using PC-ORD [McCune \& Mefford 2006]) and transformed if the assumption is not satisfied.

- Either divisive or agglomerative clustering can be used for classification. When using divisive clustering, the modified TWINSPAN (two-way-indicator species analysis [Hill 1979]) algorithm proposed by Roleček et al. (2009) as contained in JUICE (Tichý 2002) is recommended. Unlike the original version, the modified TWINSPAN algorithm does not enforce a dichotomy of classification but instead, at each step, divides only the most heterogeneous cluster of the previous hierarchical level. Thus, the application of the modified TWINSPAN algorithm results in vegetation units of similar internal heterogeneity. Pseudospecies cut levels used in the classification must be indicated (Hotanen 1990). Pseudospecies cut levels should consider the scale used during data collection (e.g. where the modified Braun-Blanquet scale was used, the following 
TABLE 1: Suggested minimal area values $\left(\mathrm{m}^{2}\right)$ for various plant communities.

\begin{tabular}{|c|c|}
\hline Vegetation type & Plot size $\left(\mathrm{m}^{2}\right)$ \\
\hline Epiphytic moss and lichen communities & $0.1-0.4$ \\
\hline Free-floating aquatic communities (e.g. Azolla and Lemna communities) & $2.0-4.0$ \\
\hline Hygrophilous pioneer communities (e.g. Isolepis and Drosera communities) & $2.0-4.0$ \\
\hline Vegetation in trampled habitats (e.g. Cynodon communities) & $2.0-4.0$ \\
\hline Lower salt marshes (e.g. Sarcocornia communities) & $4.0-9.0$ \\
\hline Open dune and sand grassland (e.g. Scaevola or Arctotis communities) & 4.0-9.0 \\
\hline Therophyte communities (e.g. Cotula or Dorotheanthus communities) & $4.0-9.0$ \\
\hline Heavily overgrazed grasslands (e.g. Stipagrostis or Aristida communities) & $4.0-9.0$ \\
\hline Upper salt marshes (e.g. Juncus communities) & $9.0-25.0$ \\
\hline Rooted floating aquatic communities (e.g. Potamogeton or Aponogeton communities) & $9.0-25.0$ \\
\hline High-altitude peatland vegetation (e.g. Limosella spp. or Haplocarpha nervosa communities) & $9.0-25.0$ \\
\hline Wetland vegetation (e.g. Stipagrostis or Ammophyla communities) & $9.0-25.0$ \\
\hline Dry and moist grassland communities (e.g. Themeda and Festuca communities) & $16.0-49.0$ \\
\hline Coastal or Kalahari dune communities (e.g. Stipagrostis or Ammophyla communities) & $16.0-49.0$ \\
\hline Weed communities (e.g. Tagetes or Argemone communities) & $25.0-100.0$ \\
\hline Perennial ruderal communities (e.g. Stipagrostis or Ammophyla communities) & $25.0-100.0$ \\
\hline Scrub communities (e.g. Leucosidea or Buddleja communities) & $25.0-100.0$ \\
\hline Nama-Karoo communities (e.g. Pentzia or Eriocephalus communities) & $25.0-100.0$ \\
\hline Succulent Karoo communities (e.g. Mesembryanthemum or Stoeberia communities) & $100.0-400.0$ \\
\hline Fynbos communities (e.g. Erica or Passerina communities) & $100.0-400.0$ \\
\hline Indian Ocean coastal belt communities (e.g. Syzygium. Phoenix or Acacia communities) & $100.0-400.0$ \\
\hline Albany thicket communities (e.g. Euphorbia or Portulacaria communities) & $100.0-400.0$ \\
\hline Savanna communities (e.g. Colophospermum or Acacia communities) & $100.0-400.0$ \\
\hline Forest communities (e.g. Androstachys or Podocarpus communities) & $400.0-1000.0$ \\
\hline Desert communities (e.g. Stipagrostis. Fenestraria or Sarcocaulon communities) & $400.0-1000.0$ \\
\hline
\end{tabular}

Desert communities (e.g. Stipagrostis. Fenestraria or Sarcocaulon communities)

Source: Adapted from Westhoff, V. \& Van der Maarel, E., 1978, 'The Braun-Blanquet approach', in R.H. Whittaker (ed.), Classification of plant communities, pp. 289-399, W Junk, The Hague. http:// dx.doi.org/10.1007/978-94-009-9183-5_9

pseudospecies cut levels are recommended: $0,5,15,25$, 50, 75).

- For fidelity measures the use of the phi coefficient of association (Chytrý et al. 2002) of each species should be calculated to determine their fidelity to each plant community as an indication of their suitability as diagnostic species. Equalisation of relevé cluster sizes (Tichý \& Chytrý 2006) is recommended before calculating the phi coefficient. One can also weigh the relative importance of common and rare species by changing the equalised size of the site groups. This can easily be achieved in the JUICE program (Tichý 2002). It is further recommended that Fisher's exact test be performed simultaneously with the calculation of the phi coefficient to exclude species with non-significant fidelity from the groups of diagnostic species.

- Description of clusters must include diagnostic, constant and dominant species. It is recommended that these are derived using JUICE, with 75, 60 and 50 recommended for lower threshold values and 80, 80 and 60 for upper threshold values for diagnostic, constant and dominant species, respectively. In addition, the Jaccard and/or Sorensen values should be reported.

- Manual rearrangement of species after automated clustering is permissible. However, rearrangement of clusters and relevés is strongly discouraged. If relevés or clusters were rearranged, it must be accompanied by a detailed justification. The dendrogram should still reflect the original clustering.
The modified TWINSPAN classification technique has been described and recommended here owing to its wide use in classification research. It is, however, important to note that other classification tools also exist. OptimClass is one of the latest methods used to determine optimal partition between the different data sets of a study area and can also be computed in the JUICE program (Tichý et al. 2010). This method is based on species with a high fidelity, which can subsequently be used as diagnostic species.

\section{Environmental gradient analysis or ordinations}

- Should the researcher wish to illustrate floristic gradients within and between plant communities or link these gradients with habitat variables, a suitable gradient analysis algorithm should be used, for example CANOCO, PC-ORD and PRIMER.

- Detrending should be used only where ordination without detrending produces uninterpretable results (e.g. where the objects are clustered together).

- It is recommended that papers report on the outcome of procedures followed to determine whether the most important environmental variables were measured (for correspondence analysis and detrended correspondence analysis). It is also recommended that if the number of environmental variables was reduced, the amount of explanatory power lost should be reported.

- The decision for the underlying model used during ordination (linear or unimodal) should be noted or explained. 


\section{Other statistical analyses, calculations and comments}

We encourage further analyses of the data using sound statistical methods to investigate some of the following aspects, where relevant:

- diversity

- richness

- evenness

- medicinal and economic value

- endemism

- conservation status and value

- production, grazing or browsing value.

\section{Tables}

Diagnostic species (see later) are used to arrange plant communities (associations) into a hierarchical classification and are presented in a phytosociological or a synoptic table. The table is the hallmark of the phytosociological study and the interpretation of the environment and its different plant communities. The table is the manifestation of a reliable and accurate research method. The arrangement of the different species groups within the table is therefore of utmost importance (Westhoff \& Van der Maarel 1980; Werger 1974):

- Phytosociological table: The phytososiological table should be arranged such that the diagnostic species group for the plant community (association) is above the diagnostic groups of the sub-associations and variants. The species groups are labelled alphabetically with an indication of diagnostic groups for easy reference. Species commonly shared amongst communities, probably representing alliances, orders and classes, are normally placed towards the bottom of the table. An example of a typical phytosociological table is included in Online Appendix 1.

- Synoptic table: Once plant communities have been identified in the phytosociological table, a synoptic table can be produced to summarise the data for each plant community (Kent 2012). In a synoptic table, each plant community is summarised in a single column containing values such as fidelity and constancy for each species. An example of a typical synoptic table is included as Online Appendix 2.

One or both of these tables must be used, as long as they contribute to a better understanding of the plant communities identified. It should, however, be noted that phi-coefficient values, used for the synoptic table, are determined from absence/presence data and not cover-abundance data. It therefore means that pseudospecies are not used in the determination of diagnostic species. Thus, one cannot solely use these results in the description of the communities, as dominant species with low phi-coefficient values will be omitted from the table. It is therefore important that the researchers use the phytosociological table to describe the dominant and co-dominant species of the community.

\section{Vegetation maps}

Effective knowledge of the different plant communities and their potential to provide habitats for animals are essential to make scientifically based management decisions for natural areas. The spatial representation of the different plant communities is therefore important. In the past, technologies to provide accurate and detailed information on the location and distribution of plant communities did not exist. Owing to technological advances floristically based classifications provide excellent information for the construction of accurate high-resolution vegetation maps (Clegg \& O'Connor 2012; Dias, Elias \& Nunes 2004). Vegetation maps of natural areas have become indispensable for managers of natural areas. These maps not only indicate the location, distribution and abundance of the different plant communities, together with rare and endemic species, but are also used to monitor changes in cover, structure and composition of the vegetation. It is therefore strongly recommended that vegetation classification and description manuscripts of conservation areas are all accompanied by vegetation maps.

\section{Classification and description of plant communities}

Plant species names used should follow the latest comprehensive South African plant species list (i.e. currently Germishuizen \& Meyer [2003], with online updates from Plants of South Africa [POSA], which can be accessed via the SANBI website, or the African Plants database [version 3.3.4] at http://www.ville-ge.ch/musinfo/bd/cjb/africa/). If the authors are of the opinion that the names of certain plant taxa are outdated or inappropriate, the use of newer names for those should be indicated clearly and referenced from the relevant published taxonomic literature.

When describing plant communities in normal local habitat classifications (not formal syntaxonomy) the following is recommended.

\section{Classification of plant communities}

The classification of different plant communities are based on total floristic composition, although they are recognised by their diagnostic species (character species and differential species). Character species are species that are mostly restricted to a specific plant community. They thus characterise the community by their occurrence in one community and by being absent or less frequent in other communities. Sub-communities are, in many cases, characterised by the presence or absence of certain species and these are referred to as differential species. These species are used mostly to define the lower syntaxa (Westhoff \& Van der Maarel 1980).

All diagnostic species identified using 'objective' statistics (phi coefficient) should be evaluated with regard to their 'robustness' as reliable and predictable indicators of a given plant community. The fewer relevés used to describe a plant community, the more subjective the interpretation of diagnostic species will be.

\section{Naming of plant communities}

According to Weber et al. (2000) names are only labels to assist in the classification of plant communities and, as such, 
they will never be wholly adequate. It is, however, more important to understand what is meant by a name than to find one that is characteristic in every respect (Weber et al. 2000). It is therefore important that basic rules are followed when naming plant communities to avoid confusion and to enable consistency. The following is therefore proposed:

- Plant community names are assigned following the same guidelines as presented in the International Code of Phytosociological Nomenclature (Weber et al. 2000) for formal syntaxonomical classification, but do not use the specified taxon epithets. According to this rule, the dominant plant name or the one that dominates the structure is second (Weber et al. 2000:749 [Article 10b]). The first name can be a diagnostic or a co-dominant species. A sub-community will start with the community name followed by a characteristic or dominant species for that sub-community (Weber et al. 2000:749 [Article 13]). Variants can have only one name, usually referring to a diagnostic or dominant species for that variant. Only an en-dash (-) is acceptable between the named taxa. Example: Plant community 1: Themeda triandra-Acacia karroo community; Sub-community 1.1: Themeda triandraAcacia karroo-Diospyros lycioides sub-community and Variant 1.1.1: Selaginella dregei variant.

- Plant community names can have physiognomic descriptors at the end, but the style should be applied consistently. Various combinations can be used, with, for example, only the major communities having descriptors. The descriptors are part of the name and should start with capital letters. Environmental attributes are not used in the plant community name. Example: Themeda triandraAcacia karroo Woodland or Themeda triandra-Acacia karroo Short Open Woodland.

- In the naming of plant communities, subjective emphasis may be placed on perennial ('non-fleeting') species that can be identified and found reliably during most years (not only during unusually good rainfall cycles). Such robust species should preferably be used in the names of plant communities whilst short-lived annuals should be avoided.

- It is also recommended that existing names for similar communities in related vegetation are retained to prevent several different names for similar communities. This should also assist when formal syntaxonomic classification of vegetation is undertaken. An attempt should therefore be made to avoid unnecessary synonomy. This implies that the researcher must be aware of the relevant literature. Referees of papers should strive to identify such synonomy.

\section{Description of plant communities}

Although a plant community is known by its dominant species, its total floristic composition is characteristic where some species have a greater diagnostic value than others (Beard 1980). It is recommended that the description of a plant community follows the standard format, namely starting with the locality and habitat (e.g. geology, land type, soil, topography, rock cover, altitude, erosion). This should be followed by the diagnostic species, which can be either listed or referred to in a table (preferred). The description is continued by listing the prominent (high-cover or abundance) and conspicuous species, their cover, growth form or any other relevant information pertaining to the community that would be useful in identifying and understanding the dynamics within the community. It is very useful to include colour photographs that illustrate typical examples of each plant community. It is highly recommended that the different communities are mapped using GIS technology and that the map is included in the paper.

\section{Syntaxonomic descriptions}

The need for formal syntaxonomic studies is recognised. Smaller and localised data sets are, however, not suitable for formal syntaxonomic descriptions. These data sets need to be combined with other compatible data sets for a particular bioregion (Mucina \& Rutherford 2006) to cover the variation of the various associations present. Formal syntaxonomic classification and descriptions are discussed in detail by Weber et al. (2000) and their recommendations should be followed for this purpose.

\section{Recommendations for concluding remarks}

It has been found that readers of scientific papers pay most attention to the first and last paragraphs of a discussion (Wenderoth 2012). It is therefore important that the first paragraph summarises the main findings of the research. In the last paragraph, the significance of the findings should be clearly explained.

The researchers can decide whether they want to have separate discussion and conclusion sections (preferred by most journals). However, it is important that the discussion should not repeat what has already been stated in the plant community descriptions; rather, the results (i.e. plant community descriptions) should be discussed in relation to the original objective or problem stated at the beginning of the paper. The results are new knowledge and should be compared critically with similar vegetation studies elsewhere. Similarities and differences should be highlighted and possible reasons given and discussed. It is important to refer continually to the results of the study and not to discuss unrelated aspects.

Other important aspects that can be discussed include endemic species, rare and endangered species, medicinal species, production, veld condition, environmental gradients within and between communities, and biodiversity of different plant communities. To emphasise the importance of phytosociological studies we cannot merely list the different plant communities and sub-communities anymore. Therefore, an effort should be made in the discussion to discuss the conservation or biodiversity value and practical implications for the different ecosystems. Concluding with applied recommendations increases the possibility that readers from other disciplines would find these studies worthwhile and interesting. It is, however, important that all recommendations be based on sound scientific theory. 
The conclusion should give a precise statement of the main findings and what they mean. The findings should also be mentioned within the context of previous findings. Implications of the study's findings, shortcomings of the study and further research or research questions should be mentioned.

\section{Concluding remarks and recommendations}

This article intended to provide broad guidelines for local phytosociological studies in conservation areas in southern Africa. We believe that by developing guidelines for vegetation classification and descriptions in the southern African context, the quality and value of papers published will increase whilst, at the same time, preventing confusion between vegetation scientists in southern Africa. Although older datasets and studies are still recognised and valid, the use of modern analytical software and techniques is strongly encouraged. This will also align southern African vegetation studies with current international trends in vegetation science.

Local phytosociological studies in South Africa are essential for efficient wildlife management programmes and conservation policies for ecosystems and biodiversity within national parks, nature reserves, private game farms and other natural areas. Vegetation classification and descriptions provide information to interpret spatial variation between species as well as an understanding of vegetation-environment relationships (Clegg \& O'Connor 2012). In addition, the predicted impacts of climate change on the environment makes the description of the vegetation of an area even more important, as it offers the only record of the current state of the environment. Thus, classifications and descriptions offer baseline information for assessing the potential changes in the environment that may result from climate change from a plant and animal perspective (Clegg \& O'Connor 2012). These data sets also play an important role in and contribute largely to formal syntaxonomic studies (Luther-Mosebach et al. 2012). This is an important reason for recommending a more standardised approach for local phytosociological studies, as it will produce compatible data sets that will assist with compiling a much-needed formal syntaxonomic classification for southern Africa.

For future development and growth of phytosociology in South Africa, the curation of datasets and literature of all phytosociological research should be administered centrally (e.g. by the South African National Biodiversity Institute or the South African Environmental Observation Network). The organisation should set up, facilitate and manage a system that will enable all researchers in this field to submit and extract electronic data and a list of publications and other literature for particular regions. Such an information system will provide researchers with relevant literature and data, which could prevent unnecessary duplication of plant community names or research, and will encourage better communication and collaboration between researchers. Ideally, South Africa should move closer to a system such as SynBioSys Europe (http://www.synbiosys.alterra.nl/ synbiosyseu/) and SynBioSys Netherlands (Schaminée, Hennekens \& Ozinga 2012) to act as a national database. Although South Africa is currently developing SynBioSys Fynbos (http://www.synbiosysfynbos.org/program.html) and SynBioSys Kruger, these are only on a regional scale.

\section{Acknowledgements Competing interests}

The authors declare that they have no financial or personal relationship(s) that may have inappropriately influenced them in writing this article.

\section{Authors' contributions}

L.R.B. (University of South Africa) was the project leader and P.J.d.P. (University of the Free State), H.B. (SANParks Scientific Services), G.J.B. (University of Pretoria), T.H.C.M. (University of Zululand) and N.B.C. (Free State Department of Economic Development, Tourism \& Environmental Affairs) made conceptual contributions.

\section{References}

Acocks, J.P.H., 1953, 'Veld types of South Africa', Memoirs of the Botanical Survey of South Africa 28, 1-92.

Barbour, M.G., Burk, J.H. \& Pitts, W.D., 1987, Terrestrial plant ecology, Benjamin Cummings, Menlo Park, CA.

Bayer, A.W., 1955, 'The ecology of grasslands', in D. Meredith (ed.), The grasses and pastures of South Africa, pp. 539-550, Central News Agency, Parow.

Beard, J.S., 1980, 'The physiognomic approach', in R.H. Whittaker (ed.), Classification of plant communities, pp. 33-64, W Junk, London.

Bews, J.W., 1918, The grasses and grassland of South Africa, Davis, Pietermaritzburg.

Bezuidenhout, H., 1993, 'Syntaxonomy and synecology of western Transvaal grasslands, South Africa', PhD thesis, Department of Botany, University of Pretoria.

Bezuidenhout, H., 1994, 'An ecological study of the major vegetation communities of the Vaalbos National Park, Northern Cape I. The Than-Droogeveld Section', Koedoe 37, 19-42. http://dx.doi.org/10.4102/koedoe.v37i2.335

Bloem, K.J., 1988, "n Plantsosiologiese studie van die Verlorenvallei natuurreservaat, Transvaal [A phytosociological study of the Verlorenvallei Nature Reserve, Transvaal]', MSc thesis, Department of Botany, University of Pretoria.

Boucher, C., 1997, 'Vegetation description and management guidelines for the Blombos private nature reserve, Riversdale District', Ecological Research Report 26, Department of Botany, University of Stellenbosch.

Braun-Blanquet, J., 1932, Plant sociology, transl. G.D. Fuller \& H.S. Conard, McGrawHill, New York.

Bredenkamp, G.J., 1975, "n Plantsosiologiese studie van die Suikerbosrandnatuurreservaat [A phytosociological study of the Suikerbosrand Nature Reserve]', MSc dissertation, Department of Botany, University of Pretoria.

Bredenkamp, G.J., 1982, "n Plantekologiese studie van die Manyeleti-wildtuin [A plant ecological study of the Manyeleti Game Reserve]', DSc thesis, Department of Botany, University of Pretoria.

Brown, L.R., 1997, 'A plant ecological and wildlife management plan of the Borakalalo Nature Reserve, North-west Province', PhD thesis, Department of Botany, University of Pretoria.

Brown, L.R. \& Bezuidenhout, H., 2000, 'The phytosociology of the farm De Rust on the Mountain Zebra National Park, Eastern Cape', Koedoe 43(1), 1-18. http://dx.doi. org/10.4102/koedoe.v43i1.204

Chytrý, M., Schaminee, H.J. \& Schwabe, A., 2011, 'Vegetation survey: A new focus for Applied Vegetetation Science', Applied Vegetation Science 14, 435-439. http:// dx.doi.org/10.1111/j.1654-109X.2011.01154.x

Chytrý, M., Tichý, L., Holt, J. \& Botta-Dukát, Z., 2002, 'Determination of diagnostic species with statistical fidelity measures', Journal of Vegetation Science 13, 79-90. http://dx.doi.org/10.1111/j.1654-1103.2002.tb02025.x

Cleaver, G., Brown, L.R. \& Bredenkamp, G.J., 2005, 'The phytosociology of the Vermaaks, Marnewicks and Buffelsklip Valleys of the Kammanassie Nature Reserve, Western Cape', Koedoe 48(1), 1-16. http://dx.doi.org/10.4102/koedoe. v48i1.162 
Clegg, B.W. \& O'Connor, T.G., 2012, 'The vegetation of Malilangwe Wildlife Reserve, south-eastern Zimbabwe', African Journal of Range \& Forage Science 29(3), 109south-eastern Zimbabwe, African Journal of Range \& Fora
131. http://dx.doi.org/10.2989/10220119.2012.744352

Coetzee, B.J., 1972, "n Plantsosiologiese studie van die Jack Scott-natuurrreservaa [A phytosociological study of the Jack Scott nature reserve]', MSc dissertation, Department of Botany, University of Pretoria.

Collins, N.B., 2011, 'Vegetation classification of pans and wetlands, Free State Province', PhD thesis, Department of Botany, University of the Free State.

Dias, E., Elias, R.B. \& Nunes, V., 2004, 'Vegetation mapping and nature conservation: A case study in Terceira Island (Azores)', Biodiversity \& Conservation 13(8), 15191539. http://dx.doi.org/10.1023/B:BIOC.0000021326.50170.66

Doing, H., 1970, 'The use of phytosociological methods in various parts of the world' Belmontia 4, 53-61.

Du Preez, P.J., 1991, 'A syntaxonomical and synecological study of the vegetation of the south-eastern Orange Free State and related areas with special reference to Korannaberg', PhD thesis, Department of Botany, University of the Orange Free State.

Du Preez, P.J. \& Brown, L.R., 2011, 'Impact of domestic animals on ecosystem integrity of Lesotho high altitude peatlands', in O. Grillo \& G. Venora (eds.), Ecosystem Biodiversity, pp. 249-270, Intech, n.p.

Dyer, R.A., 1937, 'The vegetation of the Divisions of Albany and Bathurst', Memoirs of the Botanical Surveys of South Africa 17, 1-138.

Eckhardt, H.C., 1993, 'A synecological study of the vegetation of the north-eastern Orange Free State', MSc dissertation, Department of Botany, University of Pretoria.

Edge, D.A., Cilliers, S.S. \& Terblanche, R.F., 2008, 'Vegetation associated with the occurrence of the Brenton Blue butterfly', South African Journal of Science 104 505-510. http://dx.doi.org/10.1590/S0038-23532008000600028

Edwards, D., 1967, 'A plant ecological survey of the Tugela River Basin, Natal', Memoirs of the Botanical Surveys of South Africa 36, 1-285.

Edwards, D., 1972, 'Botanical survey and agriculture', Proceedings of the Grassland Society of South Africa 7, 15-19. http://dx.doi.org/10.1080/00725560.1972.964 8660

Fuls, E.R., 1993, 'Vegetation ecology of the northern Orange Free State', PhD thesis, Department of Botany, University of Pretoria.

Geldenhuys, C.J. \& Murray, B., 1993, 'Floristic and structural composition of Hanglip forest in the Soutpansberg, Northern Transvaal', South African Forestry Journal 165, 9-20. http://dx.doi.org/10.1080/00382167.1993.9629384

Germishuizen, G. \& Meyer, N.L. (eds.), 2003, 'Plants of southern Africa: An annotated checklist', Strelitzia 14, National Botanical Institute, Pretoria. PMid:16468931

Gertenbach, W.P.D., 1978, 'Plantgemeenskappe van die gabbro-kompleks in die noordweste van die sentrale distrik van die Nasionale Krugerwildtuin [Plan communities of the gabbro-complex in the north-western section of the central district of the Kruger National Park]', MSc dissertation, Department of Botany, Potchefstroom University for Christian Higher Education.

Gotze, A.R., Cilliers, S.S., Bezuidenhout, H. \& Kellner, K., 2008, 'Analysis of the vegetation of the sandstone ridges (IB land type) of the north-eastern parts of the Mapungubwe National Park, Limpopo Province, South Africa', Koedoe 50(1) 72-81. http://dx.doi.org/10.4102/koedoe.v50i1.136

Grobler, L.E.R., 2009, 'A phytosociological study of Peat Swamp Forests in the Kosi Bay lake system, Maputaland, South Africa', MSc thesis, Department of Botany, University of Pretoria.

Hennekens, S.M., 1996, TURBOVEG: Software package for input, processing and presentation of phytosociological data, IBN-DLO, Wageningen, University of Lancaster.

Hennekens, S.M. \& Schaminee, J.H.J., 2001, 'TURBOVEG: A comprehensive database management system for vegetation data', Journal of Vegetation Science 12, 589591. http://dx.doi.org/10.2307/3237010

Henzi, S.P., Brown, L.R., Barrett, L. \& Marais, A.J., 2011, 'Troop size, habitat use, and diet of chacma baboons (Papio hamadyas urisinus) in commercial pine plantations: Implications for management', International Journal of Primatology 32, 1020-1032. http://dx.doi.org/10.1007/s10764-011-9519-6

Hill, M.O., 1979, TWINSPAN: A Fortran program for arranging multivariate data in an ordered two-way table by classification of individuals and attributes, Cornell University, New York.

Hirst, S.M., 1975, 'Ungulate-habitat relationships in a South African woodland/ savanna ecosystem', Wildlife Monographs 44, 1-40.

Hoare, D.B., 1997, 'Syntaxonomy and synecology of the grasslands of the southern parts of the Eastern Cape', MSc thesis, Department of Botany, University of Pretoria.

Hotanen, J.P., 1990, 'The effect of pseudospecies cut level settings on the results of TWINSPAN classification', Suo 41(2), 43-53.

Janecke, B.B., Du Preez, P.J. \& Venter, H.J.T., 2003, 'Vegetation ecology of the pans (playas) of Soetdoring Nature Reserve, Free State', South African Journal of Botany 69(3), 401-409.

Jurgens, N., 2004, 'A first classification of the vegetation of the Richtersveld (RSA) and directly adjacent regions in in Namibia and South Africa', Schumannia 4, 149-180.

Kay, C., Bredenkamp, G.J. \& Theron, G.K., 1993, 'The plant communities of the Golden Gate Highlands National Park in the north-eastern Orange Free State', South African Journal of Botany 59(4), 442-449.
Kent, M., 2012, Vegetation description and analysis: A practical approach, WileyBlackwell, Oxford.

Kershaw, K.A., 1964, 'Quantitative and dynamic ecology', Edward Arnold, London.

Killick, D.B.H., 1963, 'An account of the plant ecology of the Cathedral Peak areas of the Natal Drakensberg', Memoirs of the Botanical Surveys of South Africa 34 , $1-178$.

Kooij, M.S., 1990, 'A phytosociological study of the north-western Orange Free State', MSc dissertation, Department of Botany, University of Pretoria.

Le Roux, A., 1984, "n Fitososiologiese studie van die Hester Malan natuurreservaat [A phytosociological study of the Hester Malan Nature Reserve]', MSc thesis, Department of Botany, University of Pretoria.

Louw, W.J., 1951, 'An ecological account of the vegetation of the Potchefstroom area', Memoirs of the Botanical Surveys of South Africa 24, 1-105.

Luther-Mosebach, J., Dengler, J., Schmiedel, U., Röwer, I.U., Labitzky, T. \& Gröngröft, A., 2012, 'A first formal classification of the Hardeveld vegetation in Namaqualand, South Africa', Applied Vegetation Science 15(3), 401-431. http://dx.doi. South Africa', Applied Vegetation Scie
org/10.1111/j.1654-109X.2011.01173.x

Matthews, W.S., Van Wyk, A.E., Van Rooyen, N. \& Botha, G.A., 2001, 'Vegetation of the Tembe Elephant Park, Maputaland, South Africa', South African Journal of Botany 67, 573-594.

McCune, B. \& Mefford, M.J., 2006, PC-ORD. Multivariate analysis of ecological data, version 6, MJM Software, Gleneden Beach, Oregon.

McDonald, D.J., 1988, 'A synopsis of the plant communities of the Swartboschkloof, Jonkershoek, Cape Province', Bothalia 18, 233-260.

Mostert, T.H.C., 2006, 'Vegetation ecology of the Soutpansbergand Blouberg Area in the Limpopo Province', PhD thesis, Department of Botany, University of Pretoria.

Mucina, L. \& Rutherford, M.C., 2006, 'The vegetation of South Africa, Lesotho and Swaziland', Strelitzia 19, South African National Biodiversity Institute, Pretoria.

Mueller-Dombois, D. \& Ellenberg, H., 1974, Aims and methods of vegetation ecology, Wiley, New York.

Muir, J., 1929, 'The vegetation of the Riversdale area, Cape Province', Memoirs of the Botanical Surveys of South Africa 13, 1-82.

Palmer, A.R., 1981, 'A study of the vegetation of the Andries Vosloo Kudu Reserve, Cape Province', MSc thesis, Department of Botany, Rhodes University.

Pasternak, G., Brown, L.R., Kienzle, S., Fuller, A., Barrett, L. \& Henzi, S.P., 2013 'Population ecology of vervet monkeys in a high latitude, semi-arid riparian woodland', Koedoe 54(1), Art. \#1078, 9 pages. http:// dx.doi.org/10.4102/ koedoe. v54i1.1078

Pole Evans, I.B., 1922, 'The main botanical regions of South Africa', Memoirs of the Botanical Survey of South Africa 4, 49-53.

Poore, M.E.D., 1956, 'The use of phytosociological methods in ecological investigations IV: General discussion of phytosociological problems', Journal of Ecology 44, 2850. http://dx.doi.org/10.2307/2257153

Pretorius, M.L., 2012, 'A vegetation classification and description of five wetland systems and their respective zones on the Maputaland Coastal Plain', MSC dissertation, Department of Environmental Sciences, University of South Africa.

Roleček, J., Tichý, L., Zelený, D. \& Chytrý, M., 2009, 'Modified TWINSPAN 986 classification in which the hierarchy respects cluster heterogeneity', Journal
of Vegetation Science 20, 596-602. http://dx.doi.org/10.1111/j.1654of Vegetation Scien

Rubin, F. \& Palmer, A.R., 1996, 'The physical environment and major plant communities of the Karoo National Park, South Africa', Koedoe 39, 25-52. http:// communities of the Karoo National Park
dx.doi.org/10.4102/koedoe.v39i2.293

Schaminée, J.H.J., Hennekens, S.M. \& Ozinga, W.A., 2012, 'The Dutch National Vegetation Database', in J. Dengler, J. Oldeland, F. Jansen, M. Chytrý, J. Ewald, M. Finckh et al. (eds.), Vegetation databases for the 21 st century, Biodiversity \& M. Finckh et al. (eds.), Vegetation databases for the 21 st
Ecology 4, 201-209. http://dx.doi.org/10.7809/b-e.00077

Skead, J.C., 2011, Historical Incidences of Larger Land Mammals in the broader Western and Northern Cape, Centre for African Conservation Ecology, Nelson Mandela Metropolitan University.

South African Government, 2004, National Environmental Management: Biodiversity Act No. 10, South African Government, Pretoria.

Stalmans, M. \& Peel, M., 2010, 'Plant communities and landscapes of the Parque Nacional de Zinave, Mozambique', Koedoe 52(1), 1-11. http://dx.doi.org/10.4102/ koedoe.v52i1.703

Swanepoel, B.A., 2006, 'The vegetation ecology of Ezemvelo Nature Reserve Bronkhorstspruit South Africa', MSc dissertation, University of Pretoria.

Tichý, L., 2002, 'JUICE, software for vegetation classification', Journal of Vegetation Science 13(3), 451-453. http://dx.doi.org/10.1111/j.1654-1103.2002.tb02069.x

Tichý, L. \& Chytrý, M., 2006, 'Statistical determination of diagnostic species for site groups of unequal size', Journal of Vegetation Science 17, 809-818.

Tichý, L. \& Holt, J., 2006, JUICE. Program for management, analysis and classification of ecological data, Masaryk University, Brno.

Tichý, L., Chytrý, M., Hájek, M., Talbot, S.S. \& Botta-Dukát, Z., 2010, 'OptimClass: Using species-to-cluster fidelity to determine the optimal partition in classification of ecological communities', Journal of Vegetation Science 21, 287-299. http://dx.doi. org/10.1111/j.1654-1103.2009.01143.x

Van der Meulen, F., 1979, 'Plant sociology of the western Transvaal Bushveld, South Africa, a syntaxonomic and synecological study', Dissertiones Botanicae 49, 1-191. 
Van der Walt, P.T., 1980, 'A phytosociological reconnaissance of the Mountain Zebra National Park', Koedoe 23, 1-32. http://dx.doi.org/10.4102/koedoe.v23i1.632

Van Rooyen, N., 1983, 'Die plantegroei van die Roodeplaatdam natuurreservaat II. Die plantgemeenskappe [The vegetation of the Roodeplaatdam Nature Reserve II. The plant communities]', South African Journal of Botany 2, 115-125.

Van Staden, P.J., 2002, 'An ecological study of the plant communities of the Marakele National Park', MSc thesis, Department of Botany, University of Pretoria.

Weber, H.E., Moravec, J. \& Theurillat, J.P., 2000, 'International Code of Phytosociological Nomenclature. 3rd edition', Journal of Vegetation Science 1, 739-768.

Wenderoth, P., 2012, How to write a scientific research paper, viewed 10 May 2012 from http://vision.psy.mq.edu.au/ peterw

Werger, M.J.A., 1973, 'Phytosociology of the upper Orange River Valley, South Africa: A syntaxonomical and synecological study', DSc thesis, Science Department, Catholic University of Nijmegen.

Werger, M.J.A., 1974, 'On concepts and techniques applied in the Zurich-Montpellier method of vegetation survey', Bothalia 11, 309-323.
Werger, M.J.A. \& Coetzee, B.J., 1977, 'A phytosociological and phytogeographical study of the Augrabies National Park, Republic of South Africa', Koedoe 20, 11-51. http://dx.doi.org/10.4102/koedoe.v20i1.929

Westfall, R.H., Van Staden, J.M., Panagos, M.D., Breytenbach, P.J.J. \& Greeff, A., 1996 'Scale related vegetation sampling', ARC-Range and Forage Institute, Pretoria.

Westhoff, V. \& Van der Maarel, E., 1978, 'The Braun-Blanquet approach', in R.H. Whittaker (ed.), Classification of plant communities, pp. 289-399, W Junk, The Hague. http://dx.doi.org/10.1007/978-94-009-9183-5_9

Westhoff, V. \& Van der Maarel, E., 1980, 'The Braun-Blanquet approach', in R.H. Whittaker (ed.), Classification of plant communities, pp. 287-399, W Junk, The Hague.

Zietsman, M.M., 2003, 'Phytosociological study of Andrews field and Tsaba-Tsaba nature reserve, Bredasdorp district, Western Cape', MSc dissertation, Department of Botany, University of Pretoria.

Zietsman, M.M. \& Bredenkamp, G.J., 2006, 'Dune vegetation and coastal thicket communities in threatened limestone fynbos of Andrews field and Tsaba-Tsaba nature reserve Struisbaai, Western cape', Koedoe 49, 33-47. http://dx.doi. org/10.4102/koedoe.v49i1.110 